\title{
Hubungan Media Pornografi dengan Perilaku Seksual Pranikah pada Remaja
}

\author{
Etik Mardyantari ${ }^{1}$, Muhamad Aidil Firdauz ${ }^{2}$, Lia Ratnasari Pujiningtyas ${ }^{3}$, Hasli Yutifa ${ }^{4}$, \\ Susanto ${ }^{5}$, Sri Sunarsi ${ }^{6}$ \\ ${ }^{1}$ STIKes Surya Mitra Husada Kediri \\ ${ }^{2}$ Fakultas Kesehatan Universitas Udayana \\ ${ }^{3}$ Fakultas Kesehatan Masyarakat Universitas Muhammadiyah Surakarta \\ ${ }^{4}$ Fakultas Ilmu Kesehatan Universitas Riau \\ ${ }^{5}$ Fakultas Psikologi Universitas Ahmad Dahlan \\ ${ }^{6}$ Akademi Kebidanan YLPP Purwokerto \\ Email : etikiskandar14@gmail.com
}

Received 21 April 2018; Accepted 8 May 2018; Published 15 May 2018

\begin{abstract}
ABSTRAK
Jurnal yang ditulis oleh penulis ini bertujuan untuk mengetahui hubungan media sosial (pornografi) dengan perilaku seksual pranikah pada remaja. Sample pada jurnal ini adalah remaja usia $15-24$ tahun yang belum menikah. Metode penelitian yang digunakan adalah dengan pendekatan cross sectional. Hasil penelitian pada kelima jurnal ini menunjukkan 3 jurnal menuliskan bahwa ada hubungan yang signifikan antara media pornografi dengan perilaku seksual pranikah pada remaja ( $\mathrm{p}$ value $=0.000<0.05$ ), sedangkan 2 jurnal menuliskan bahwa tidak ada hubungan yang signifikan antara media pornografi dengan perilaku seksual pranikah pada remaja $(\mathrm{p}$ value $=0.615 / 0.852>0.05)$.
\end{abstract}

Kata Kunci : Media sosial, perilaku seksual pranikah dan remaja.

Copyright $(92018$ STIKes Surya Mitra Husada

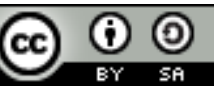

This is an open-acces article distributed under the terms of the Creative Commons Attribution-ShareAlike 4.0 International License. 


\section{PENDAHULUAN}

Media pornografi adalah merupakan konsep antar pribadi, medium penyimpanan dan medium informasi yang mengandung unsur pornografi ( Wen dalam Bungin, 203). Sedangkan pornografi sendiri memiliki arti adalah gambar, sketsa, ilustrasi, foto, tulisan, suara, bunyi, gambar bergerak, animasi, kartun, percakapan, gerak tubuh, atau bentuk pesan lainnya melalui berbagai bentuk media komunikasi dan atau pertujukan dimuka umum, yang memuat kecabulan atau ekspoitasi seksual yang melanggar norma kesusilaan dalam masyarakat (UU RI no. 44, 2008). Terbukanya media informasi di media sosial terutama

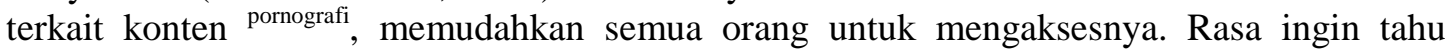
manusia yang besar, mengakibatkan banyak orang yang membuka media sosial, terutama konten pornografi. Hal ini dikarenakan pornografi adalah sesua hal yang sangat menarik untuk dilihat dibandingkan dengan konten- konten yang lainnya.

Remaja adalah salah satu orang yang banyak mengakses konten pornografi di media sosial. Remaja akhir atau remaja yang beranjak dewasa (emerging adulthood) terjadi proses penyempurnaan pertumbuhan fisik dan perkembangan aspek-aspek psikis yang dimulai sejak masa sebelumnya, yang mengarah pada kematangan yang sempurna (Al-Mighwar, 2006). Remaja mempunyai rasa ingin tahu yang besar, namun remaja justru kurang mendapatkan kesempatan untuk mendapatkan informasi dan pengetahuan yang cukup berkaitan dengan kesehatan reproduksi. Sebagai bentuk rasa keingintahuannya, maka remaja mencari informasi sebanyak-banyaknya. Remaja seringkali merasa tidak nyaman atau tabu untuk membicarakan masalah seksualitas dan kesehatan reproduksinya. Akan tetapi karena faktor keingintahuannya, mereka akan berusaha untuk mendapatkan informasi ini. Seringkali remaja merasa bahwa orangtuanya menolak membicarakan masalah seks sehingga mereka kemudian mencari alternatif sumber informasi lain seperti teman atau media internet (Darwisyah, 2009). Secara psikologis naluri seks pada remaja sangat tinggi, hal ini disebabkan kelenjar-kelenjar seks (gonads). Kehidupan moral remaja yang berkaitan dengan dengan pengaruh kuat bekerjanya gonads sering menimbulkan konflik dalam diri mereka sendiri. Antara dorongan seks dengan pertimbangan moral seringkali saling kontradiktif, karena di satu sisi moral dan etika telah demikian berkembang dan di sisi lain masih adanya dorongan-dorongan seks. Bagi remaja yang ber-sekolah atau mahasiswa, masalah moral ini telah banyak diperhitungkan secara matang sehingga mereka dapat mempertimbangkan akibat negatif melakukan hubungan seks diluar nikah bagi pendidikannya. Namun demikian, bila dorongan seks yang terlalu kuat itu mendorong dalam konflik yang sangat kuat mereka akan melakukan kegiatan seksual, yang salah satunya adalah perilaku seksual pranikah.

Perilaku sex pra nikah adalah tingkah laku yang didorong oleh hasrat seksual baik yang dilakukan oleh diri sendiri, lawan jenis, maupun sesama jenis tanpa adanya ikatan pernikahan menurut agama (Sarwono, 2003). Remaja melakukan berbagai macam perilaku sexual beresiko yang terdiri atas tahapan-tahapan tertentu yaitu dimulai dari berpegangan tangan, cium kening, cium basah, berpelukan, memegang atau meraba bagian sensitif, petting, oral sex dan bersenggama (sexual intercourse) (irawati, 2002). Beberapa studi melaporkan bahwa dampak buruk dari seks pranikah ada banyak, diantaranya kehamilan usia dini dan penyakit menular seksual (Ojira, et al, 2012).

\section{METODE}

Pendekatan penelitian yang digunakan adalah pendekatan cross sectional. Populasi yang digunakan adalah remaja dengan rentang usia $15-24$ tahun yang belum menikah. Penentuan sample penelitian dengan menggunakan teknik random sampling (pada 4 jurnal) dan puposive sampling (1 jurnal). 


\section{HASIL DAN PEMBAHASAN}

Hasil penelitian pada 3 jurnal menunjukkan bahwa ada hubungan yang signifikan antara hubungan media pornogrfi dengan perilaku seksual pranikah pada remaja. Hal ini dibuktikan pada jurnal yang ditulis Sri Sunarsih dkk, bahwa sebagian besar remaja putra di SMK Wongsorejo Gombong terkena frekuensi paparan media pornografi lebih dari $1 \mathrm{x}$ per bulan yaitu sebanyak 41 siswa (45\%) dan sebagian besar remaja putra di SMK Wongsorejo Gombong sudah pernah masturbasi> 12 x per bulan sebanyak 47 siswa $(51 \%)$. Terdapat hubungan antara frekuensi paparan media pornografi dengan frekuensi perilaku masturbasi remaja putra di SMK Wongsorejo Gombong Tahun 2010 dengan $\rho$ value $0,000<0,05$.

Jurnal yang ditulis Susanto, mengatakan bahwa ada hubungan positif yang sangat signifikan antara sikap terhadap media pornografi dengan perilaku seksual. Berdasarkan hasil tersebut hipotesis yang diajukan pada penelitian ini diterima, hal ini ditunjukkan dengan koefisien korelasi ( xy r ) sebesar 0,663 dan peluang kesalahan $\mathrm{p}$ sebesar 0,000 ( $\mathrm{p}<0,01$ ). Nilai (r) yang positif menunjukkan bahwa kenaikan nilai variabel yang satu yaitu variabel bebas (x) yang berupa sikap terhadap media pornografi akan diikuti dengan naiknya variabel yang lain, dalam hal ini variabel tergantung (y) yaitu perilaku seksual, artinya semakin positif sikap terhadap media pornografi maka semakin tinggi pula perilaku seksual pranikah, sebaliknya jika semakin negatif sikap terhadap media pornografi maka semakin rendah pula perilaku seksual.

Jurnal ketika yang ditulis oleh Hasli Yustifa dkk, menyatakan bahwa Hasil analisa hubungan frekuensi keterpaparan pornografi terhadap perilaku seksual remaja di Pekanbaru, diperoleh bahwa untuk perilaku seksual tidak beresiko lebih banyak terpapar frekuensi jarang yaitu sebanyak 38 orang $(65,5 \%)$ dan untuk perilaku seksual beresiko responden lebih banyak menggunakan frekuensi sering yaitu berjumlah 31 orang $(93,9 \%)$. Berdasarkan hasil penelitian terhadap 99 orang responden didapatkan hasil uji statistik (Chi Square) yaitu $p$ value sebesar 0,000 yang berarti kecil dari $\alpha(0,05)$. Maka dapat disimpulkan ada hubungan yang signifikan antara frekuensi keterpaparan pornografi terhadap perilaku seksual remaja di Pekanbaru (H0 ditolak). Hasil analisis bivariat menunjukkan adanya hubungan yang bermakna antara frekuensi keterpaparan pornografi terhadap perilaku seksual remaja ( $\mathrm{p}$ value: $0,000)$.

Dua jurnal menyatakan bahwa tidak ada hubungan yang signifikan antara media pornografi dengan perilaku seksual pranikah pada remaja. Pada jurnal yang ditulis Lia Ratnasari P, menyebutkan bahwa dari 136 responden 19,1\% diantaranya telah melakukan perilaku seks pranikah. Dari seluruh responden laki-laki, 26,3\% telah melakukan perilaku seks pranikah. Sedangkan dari seluruh responden perempuan $8,9 \%$ telah melakukan seks pranikah. Frekuensi paparan pornografi tidak berpengaruh signifikan terhadap perilaku seks pranikah $(\mathrm{p}=0,615)$. Nilai $\mathrm{PR}=1,194$ dan $95 \% \mathrm{CI}=0,599-2,581$. Ini berarti frekuensi pornografi sering sebagai faktor resiko namun tidak signifikan.

Jurnal yang ditulis Muhammad idil F, juga menyatakan bahwa Hasil analisis dengan uji Fisher's Exact Test diketahui bahwa tidak ada hubungan antara penggunaan media sosial dengan perilaku seks siswa. Nilai signifikansi diketahui bahwa nilai p-value 0,852>0,05 sehingga $\mathrm{H} 0$ diterima yang menunjukkan tidak adanya hubungan antara penggunaan media sosial dengan perilaku seks siswa.

Dari kelima (5) jurnal memberikan hasil bahwa ketiga (3) jurnal menyatakan bahwa ada hubungan signifikan antara media pornografi dengan perilaku seksual pranikah. Sedangkan dua (2) jurnal menyatakan bahwa media pornografi merupakan salah satu faktor pendukung terjadinya perilaku seksual pranikah, meskipun hasil pengolahan SPSS tidak ada hubungan yang siginifikan (karena $p$ value $>0.05$ ) antara media pornografi dengan perilaku seksual pranikah pada remaja. 


\section{ANALISIS KRITIS}

Metode penelitian kuantitatif dengan pendekatan cross sectional adalah penelitian yang berfungsi mencari hubungan antara 2 variabel atau lebih dalam satu waktu. Peneliti dengan metode ini sudah memberikan batasan variabel - variabel yang akan diteliti. Kelebihan metode ini adalah 1) penelitian berjalan sistematis 2) mampu memanfaatkan teori yang ada 3) penelitian lebih berjalan obyektif 4) penelitiah lebih spesifik, jelas dan rinci 5) ukuran penelitian besar. Sedangkan kelemahan metode kuantitatif adalah 1) pengambilan data cenderung yang berasal dari nilai tertingii 2) penelitian tidak subyektif 3) orientasi hanya terbatas pada nilai dan jumlah 4) dibatasi oleh peluang untuk menggali responden dan kualitas perangkat pengmpul data orisinal 6) keterlibatan periset umumnya terbatas.

\section{KESIMPULAN}

1. Tiga jurnal menyatakan bahwa ada hubungan signifikan antara media pornografi dengan perilaku seksuap pranikah remaja.

2. Dua jurnal menyatakan bahwa media pornografi merupakan faktor pendukung perilaku seksual pranikah pada remaja, meskipun tidak signifikan, artinya ada faktor lain yang dimungkinkan mendorong remaja melakukan sekual pranikah, misalnya tekanan dari teman/ pacar.

\section{DAFTAR PUSTAKA}

Azwar, S. (2010). Metode Penelitian. Yogyakarta : Pustaka Pelajar.

Depkes. (2010). Kesehatan remaja : Problem dan solusinya. Jakarta : Salemba Medika. 2012.

Yutifa, H., Priastiana, A., Dewi \& Misrawati. (2015). Hubungan paparan pornografi melalui elektronik terhadap perilaku seksual remaja. JOM Vol. 2 No. 2. Riau : Prodi S1 Keperawatan Universitas Riau.

Pujinintyas, L.R. (2014). Hubungan penggunaan media sosial dengan perilaku seks siswa SMP di Surakarta. Fakultas Ilmu Kesehatan : Universitas Muhamadiyah Surakarta.

Firdauz, M.A. Hubungan antara frekuensi paparan pornografi dengan perilaku seksual pranikah pada remaja SMA/sederajat di wilayah kerja puskesmas sukawati kabupaten gianyar bali 2014. ISM Vol. 2 No. 1. Fakultas Kedokteran Universitas Udayana.

Notoatmodjo, S. (2012). Metodologi Penelitian Kesehatan. Jakarta : Rineka Cipta.

Susanto. Hubungan antara sikap terhadap media pornografi dengan perilaku seksual pranikah pada remaja, Fakultas Psikologi : Univeritas Ahmad Dahlan.

Sarwono, W.S. (2003). Psikologi Remaja. Jakarta : Grafindo Persada.

Sunarsih, S., Purwati, S., \& Khosidah, A. (2010). Hubungan frekuensi paparan media pornografi dengan frekuensi perilaku masturbasi remaja putra di smk wongsorejo gombong kebumen. Jurnal Ilmiah Kebidana Vol. 1 No. 1. Purwokerto : Akademi Kebidanan YLPP. 